\title{
Políticas, resistencias y diásporas religiosas en perspectiva transcultural: gitanos evangélicos en España e indígenas católicos en México
}

\section{Policies, resistances and religious diasporas in a cross cultural perspective: evangelical Gypsies in Spain and Catholics Indigenous in Mexico}

\author{
Manuela CANTÓN DELGADO \\ Departamento de Antropología Social. Universidad de Sevilla \\ mcanton@us.es \\ Pilar GIL TÉBAR \\ Departamento de Historia I. Universidad de Huelva \\ pilar.gil@dhis1.uhu.es
}

Recibido: 8 de febrero de 2011

Aceptado: 14 de marzo de 2011

\begin{abstract}
Resumen
Impulsando la emergencia de nuevos actores políticos, definiendo mediaciones novedosas o resolviéndose como resistencias para preservar la tradición o encarar sus dislocaciones, la innovación religiosa sigue ofreciendo a los científicos sociales un asombroso y constante estallido de fragmentaciones, transformismos, hibridaciones y nuevas cartografías que desdibujan los límites con los que se pensaban las religiones. Este artículo versará sobre dos etnografías situadas en perspectiva. Una de ellas muestra cómo la Teología de la Liberación proporciona a la población indígena espacios en los que plantear nuevos modelos de convivencia, objeto del trabajo que ha venido realizando Pilar Gil en la diócesis de San Cristóbal de Las Casas, Chiapas (México). La segunda se detiene en el análisis de la incipiente construcción política de las organizaciones evangélicas gitanas desde un abordaje multisituado, así como su expansión en redes europeas y latinoamericanas, investigación de la que se ocupa Manuela Cantón.
\end{abstract}

Palabras clave: Antropología de la religión, política, etnicidad, transculturalidad.

\begin{abstract}
Driving the emergence of new political actors, defining new mediations or resulting in resistances whose aim is to preserve tradition or confront their displacement, religious innovation continues to offer social scientists astonishing and constant splintering, transmutations, hybridity and new maps blurring the limits of what is thought about religions. This paper deals with two ethnographies in this perspective. One of these shows how Liberation Theology provides the indigenous population a forum in which they can find new models of co-existence. This is the aim of the work carried out by Pilar Gil in the dioceses of San Cristóbal de Las Casas, Chiapas (Mexico). The second focuses on the analysis of the embryonic political
\end{abstract}


construction of the evangelical gypsy organisations from a multicentric approach, as well as its expansion in European and Latin American networks, and is the aim of the research Manuela Cantón has been carrying out for the last few years.

Keywords: Anthropology of Religion, Politics, Ethnicity.

Referencia normalizada: Cantón Delgado, M. \& Gil Tébar, P. (2011). Políticas, resistencias y diásporas religiosas en perspectiva transcultural: gitanos evangélicos en España e indígenas católicos en México. Revista de Antropología Social, 20, 77-108.

SUMARIO: 1 . Introducción. 2. La construcción política del evangelismo gitano. 3. La construcción política del catolicismo indígena. 4. Reflexiones finales. 5. Referencias bibliográficas.

A Pilar Sanchiz Ochoa

\section{Introducción}

El estudio antropológico de la innovación y la movilidad religiosa está volviéndose un ámbito de interés creciente en las Ciencias Sociales, tras el prolongado letargo que fue anunciado por Clifford Geertz hace ya unas décadas (1988). Las expresiones más dinámicas de esa innovación —en un escenario como el de la globalización y movilidad contemporáneas - suceden por lo común en contextos modestos, mudables y poco visibles, y frecuentemente consisten en giros y resignificaciones imprevistas de sistemas y prácticas religiosas que la modernidad tardía ha reinventado, modernizado y resituado. Impulsando la emergencia de nuevos actores políticos, definiendo mediaciones novedosas o resolviéndose como resistencias para preservar la tradición o encarar sus dislocaciones, la innovación religiosa sigue ofreciendo a los científicos sociales un asombroso escenario de fragmentaciones, transformismos, hibridaciones y nuevas cartografías que desdibujan los límites de un campo, el de la religión y sus simbolismos, sumido en un proceso de continuo desbordamiento. Es un campo ensanchado donde se dan cita nuevas rivalidades, desplazamientos insensibles de agentes dedicados al cuidado, la salud, la curación espiritual, capaces de hablar al cuerpo, hacer ver, hacer creer y desencadenar con ello acciones completamente reales (Bourdieu, 1988).

La sociología de la religión ha venido ganando terreno en la teorización y la exploración macroscópica de las religiones en los intersticios urbanos contemporáneos; sin embargo, desde estas páginas defendemos el papel de la indagación etnográfica para probar que la heterogeneidad está obstinadamente instalada en la vida cotidiana desbordando el esquematismo de los extensos diagnósticos basados en promedios, en cálculos estadísticos y en la identificación de totalidades compactas allí donde la etnografía - más bien - desentraña y desdibuja. De los Nuevos Movimientos Religiosos a las formas locales de sistemas religiosos globalizados, flexibles, viajeros y de crecimiento reticular, pasando por la presencia de las religiones en Internet y las transformaciones intramuros de la llamada, no sin cierta ambigüedad, religiosidad popular, lo cierto es que estamos asistiendo al constante 
surgimiento de nuevas y/o renovadas reformulaciones de carácter religioso, con una presencia en aumento de lo que podríamos definir como comunidades transnacionales de creyentes basadas en la pertenencia religiosa, principalmente debidas a la movilidad que propician los intensos flujos migratorios y al papel que éstos desempeñan en los procesos contemporáneos de intercambio, movilidad y diversificación religiosa.

La antropología social, al menos en España, se ha sumado tardíamente al interés que despierta este cambio de escenario. El cambio se produce en un Estado formalmente laico que ha pasado, en pocos años, de un panorama dominado por un catolicismo hegemónico, omnipresente, ubicuo, a la paulatina implantación del pluralismo confesional y la creciente visibilidad de modalidades extremadamente diversas de itinerarios, intercambios y filiaciones religiosas, así como de nuevos espacios organizativos vinculados a ellas y de liderazgos o mediaciones alternativas. Relegar la religión al ámbito de lo privado, apartarnos del eclesiocentrismo o insistir en la necesidad de una perspectiva descentrada, extrañada, perspectivista y respetuosa con la diversidad, no evitará que la religión se haga presente, como hace años que no sucedía, en el debate público a través de polémicas como las del uso del velo, los crucifijos en las aulas, el origen religioso de muchos valores laicos o, sin ir más lejos, de las controvertidas declaraciones de la última visita del Papa a Barcelona, en noviembre de 2010, cuando se pronunció sobre lo que califica como laicismo radical decretado por el gobierno socialista, los parecidos entre el actual anticlericalismo y el de los años treinta del pasado siglo, o la ruptura con los valores que la Iglesia desearía universales acerca del matrimonio tradicional, el aborto o la familia.

Se aborden desde la búsqueda individual, como disciplina corporal o fuente de normatividad ética, como elemento transformador de la vida comunitaria o del tejido asociativo, como vertebradores de procesos políticos de producción de liderazgos o canalizadores de las dislocaciones provocadas por las intensas sacudidas del capitalismo tardío, es decir, tanto si nos inclinamos más del lado del sujeto, los significados, la experiencia personal o la construcción subjetiva del orden colectivo, como si preferimos un abordaje más atento al marco normativo y el orden social y político, sea como sea que los miremos, resulta improcedente y anacrónico continuar asumiendo una mirada eurocéntrica e iluminista hacia los fenómenos religiosos. No es sensato seguir atribuyéndoles un papel reducido al de meros invitados imprevistos al festín de la producción contemporánea de hibridación identitaria, movilidad y multipertenencia. La antropología social y cultural empieza a interesarse por el ambiguo y perturbador reavivamiento de un campo ciertamente clásico, el de la antropología de la religión, casi siempre mirado con escepticismo, impugnado, incómodo y quizás por ello más propenso a contraer los padecimientos ya endémicos de la disciplina. No se suele reparar en la posibilidad de que la religión deba ser vista antes como una perspectiva que como una dimensión irreductible de la cultura con sustancia ontológica propia (Cornejo, 2008: 16; Sansi, 2007: 140; Berger, 1981:13-15). A veces se olvida que la investigación antropológica de los sistemas de sentido, representaciones y prácticas religiosas no debería ser vista como algo 
lejano, periférico y de otros, o considerada más excepcional o más inmanejable que el tratamiento de las prácticas económicas, políticas, terapéuticas, festivas y otras. El manejo antropológico de la religión sigue marcado por un exceso de trascendencia y de apego a lo extraordinario que queda contrariado por el carácter terrenal, práctico y mundano de las vidas de los creyentes reales. Las religiones están, como ya reflexionara Weber, orientadas primeramente hacia este mundo y no tanto al más allá, sus prácticas son intencionales y dirigidas a propósitos útiles. En este sentido, el de los esfuerzos por destrascendentalizar la religión, Weber declaraba que "el actuar o el pensar religioso o mágico no puede abstraerse... del círculo de las acciones con vistas a un fin de la vida cotidiana, y menos si pensamos que los fines que persigue la religión son de naturaleza predominantemente económica" (Weber, 1992: 328).

Pues bien, uno de los efectos de aquella más temprana presencia de la sociología de la religión en contextos en los que la secularización no permitía imaginar la vuelta de las religiones, es que quienes desde la antropología social nos interesamos por esos nuevos escenarios hemos acabado enredados en la ya larga historia del desmentido de la tesis sociológica de la secularización, o al menos de algunas de sus versiones más esquemáticas. Lo que sucede es que en América Latina, donde las dos autoras del presente texto han trabajado extensamente, esa tesis se desmiente sola. En Europa es de desear que sus defensores perciban lo que se ha repetido hasta la saciedad, que las religiones no han reaparecido, simplemente nunca llegaron a marcharse, y que la secularización no las ha extirpado, sólo las ha modernizado, resituado y puesto al día. Puede que en cierto sentido haya salido debilitada la religión como institución, pero en todo caso ésta sería una perspectiva en rigor eclesiocéntrica. Al igual que ha sucedido con la Antropología Urbana, que ha visto cómo los conjuntos sociales a los que se dedicaban clásicamente los antropólogos -indígenas, campesinos - se encuentran, cada vez más, en las ciudades, la antropología de la religión en Europa, y particularmente en España, ha de encarar el hecho de que la innovación, diversificación y la movilidad étnica y religiosa ya no son cosa de países en vías de desarrollo o el resultado de una modernidad fallida. Decididamente, la inmigración ha burlado esas fronteras estables y provocado desplazamientos e intersecciones no previstas en un campo religioso y simbólico cada vez más elástico y complejo ${ }^{1}$.

Este artículo versará sobre dos etnografías situadas en perspectiva. Una de ellas muestra cómo la Teología de la Liberación - y, con ella, la Teología Indígena y la Pastoral de mujeres - proporciona a la población indígena espacios en los que plantear nuevos modelos de convivencia, objeto del trabajo que ha venido realizando Pilar Gil Tébar en la diócesis de San Cristóbal de Las Casas, Chiapas (México). La otra se detiene a analizar la incipiente construcción política de las organizaciones evangélicas gitanas en España, así como su expansión en redes europeas y

${ }^{1}$ Véase el interesante trabajo de Cristina Sánchez Carretero sobre las revitalizaciones afrodominicanas en Madrid, entre los llamados servidores de misterios o practicantes de vudú dominicano (Sánchez-Carretero, 2008). 
latinoamericanas, investigación que actualmente lleva a cabo Manuela Cantón. Empezamos por ésta.

\section{La construcción política del evangelismo gitano}

Mientras son ya incontables las investigaciones sociológicas y antropológicas sobre el papel político que las iglesias protestantes han jugado en la historia de casi todas las repúblicas latinoamericanas, desde que se iniciaron los diversos procesos independentistas y se instalaron gobiernos liberales en muchas de ellas ${ }^{2}$, sin embargo en España los estudios que contemplan la ecuación religión —evangélica_-políticas - étnicas - en relación a la comunidad gitana apenas si han comenzado. Del mismo modo están aún por explorar las redes del evangelismo gitano en Europa y América Latina o quedan por articular las aportaciones más relevantes de los todavía escasos especialistas en la materia (Teresa San Román, Paloma Gay y Blasco, Carmen Méndez, Magdalena Slavkova, Ruy Llera Blanes, Tomas Hrustic, David Thurfjell o Tatiana Podolinska, entre otros ${ }^{3}$ ). El análisis de la diversidad de factores que intervienen en los procesos de expansión del evangelismo pentecostal o

${ }^{2}$ En Latinoamérica se cuentan por centenares las contribuciones que abordan, tanto desde el análisis de casos concretos como abarcando escenarios más amplios, la expansión del protestantismo evangélico en contextos de hegemonía católica. Desde los estudios pioneros de Christian Lalive D’Epinay y Emilio Willems, hasta los trabajos socio-históricos de Jean-Pierre Bastian, David Martin, Christian Parker y Paul Freston, o los más antropológicos de David Stoll, Virginia Garrard y Alejandro Frigerio, el inventario de sociólogos y antropólogos que podemos considerar ya clásicos se vuelve interminable. Manuela Cantón se ocupó, entre fines de los años ochenta y mediados de los noventa, de analizar los impactos locales del protestantismo evangélico tanto en el occidente de Guatemala como en el sureste de México (Chiapas). Hoy abundan los equipos de investigación dedicados a explorar la creciente actividad de estos grupos religiosos en toda América Latina y asimismo en Brasil, donde los trabajos de Paul Freston, Marion Aubreé, Flavio Pierucci, Carlos Rodrigues Brandâo, Fernando Giobellina, Júlia Miranda o Lisías Nogueira, han contribuído a clarificar la inserción de los protestantismos, y muy particularmente la IURD, así como su papel en el espacio público y político, en los procesos migratorios del interior del Brasil a las grandes ciudades, el empoderamiento político de los evangelismos pentecostales y la emergencia de "candidatos de iglesia" que se postulan regularmente para los comicios brasileños - como ha sido el caso de Marina da Silva en las pasadas elecciones de 2010 -

${ }^{3}$ Las principales aportaciones realizadas en la Antropología Social española sobre comunidades gitanas y sobre problemas conceptuales relacionados con la exclusión y la xenofobia, así como su relevancia en la construcción histórica de las identidades gitanas, son debidas a la extensa trayectoria de la antropóloga Teresa San Román. Por su parte, la investigación de campo más amplia sobre las formas y los impactos del pentecostalismo gitano realizada en España hasta el momento ha sido desarrollada por Manuela Cantón - junto a un equipo de antropólogos entre quienes se cuentan Salvador Medina, Cristina Marcos e Ignacio Mena-. Se trató de un proyecto antropológico desarrollado entre los años 1998 y 2005 que abordó los usos del pentecostalismo en diversos contextos gitanos bajoandaluces, reconstruyendo y explicando el surgimiento histórico y la rápida multiplicación de agrupaciones religiosas de composición, financiación y liderazgo gitanos. Este estudio se centró en el análisis de los procesos de apropiación y resignificación cultural desencadenados a partir de las conversiones, la aparición de nuevos espacios organizativos, la exploración de los impactos socio-familiares y de género, y los usos económicos, terapéuticos y etno-políticos de las nuevas adhesiones religiosas. Los resultados están recogidos en una veintena de artículos y en el libro Gitanos pentecostales. Una mirada antropológica a la Iglesia Filadelfia en Andalucía (2004). 
el alcance de su impacto cultural y político entre los gitanos europeos en general, españoles en particular, permanecen aún en gran medida ausente de los grandes foros académicos de discusión sobre el avance del pluralismo confesional en Europa.

Las razones son múltiples y complejas, pero en parte esta circunstancia se debe a la escasez de investigaciones socio-antropológicas que se ocupen de la presencia no sólo de iglesias protestantes históricas de notorio arraigo ${ }^{4}$, sino particularmente de las organizaciones de filiación pentecostal, cuyo mayor crecimiento se ha registrado a lo largo de los últimos veinte años principalmente a partir de la entrada regular de inmigrantes latinoamericanos a España y, ya desde antes, entre la población gitana asentada en Cataluña, Levante y Andalucía. No hay en las Ciencias Sociales españolas una tradición de estudios que aborde este fenómeno desde la sociología de la religión, en general más atenta a las consecuencias de los procesos de secularización en las sociedades urbanas occidentales y las extensas visiones de conjunto que al conocimiento etnográfico, cualitativo y micro de las expresiones religiosas emergentes; pero tampoco desde la antropología de la religión que, en términos generales, se ha mostrado más interesada en los vínculos entre las expresiones del catolicismo popular y los fenómenos festivos 5 .

Los gitanos han llegado al siglo XXI como la primera minoría étnica del Estado español ${ }^{6}$. Sus identidades históricas se han ido fragmentando y reajustando en función de una multiplicidad de factores, entre los que en las últimas décadas hay que destacar las políticas sociales que las distintas administraciones públicas han promovido para favorecer la integración de la minoría. Con frecuencia estas políticas de reubicación e integración han generado conflictividad, tanto intraétnica como con la sociedad mayoritaria. Aunque la vida cotidiana de los grupos gitanos

${ }^{4}$ Las religiones musulmana, judía y cristiano-evangélica — protestante - fueron reconocidas en 1992 con el gobierno socialista presidido por Felipe González como religiones de notorio arraigo, cuya presencia es muy anterior a la Ley Orgánica de Libertad Religiosa, aprobada en 1980. En 2003 alcanzaron el estatus de notorio arraigo los mormones - Iglesia de Jesucristo de los Santos de los Ultimos Días-, en 2007 los Testigos de Jehová y más recientemente el budismo — reconocido su notorio arraigo el 28 de octubre de 2007 -

${ }^{5} \mathrm{Si}$ bien en los últimos diez años la antropología social está abordando el estudio de las religiones emergentes desde una perspectiva más compleja y problematizada. Las Dras. Mónica Cornejo - Universidad Complutense de Madrid - y Manuela Cantón organizaron, junto con el Dr. Ruy Llera Blanes - Universidade de Lisboa- un simposium titulado Teorías y prácticas emergentes en Antropología de la Religión, en el XI Congreso Estatal de Antropología celebrado en San Sebastián — septiembre de 2008- Las numerosas ponencias publicadas mostraban claramente esa tendencia a presentar las religiones emergentes en su complejidad, mostrando intersecciones, redes, flujos, recombinaciones y transferencias. Y no sólo éso: el grupo de investigadores coordinado por Joan Prat dio, hace ya algunos años, resultados muy notables en la investigación con minorías religiosas. Destacamos los dos volúmenes que el desaparecido Arxiu d'etnografía de Catalunya dedicó a Heterodoxos, herejes y sectarios, y el excelente libro El estigma del extraño. Un ensayo antropológico sobre sectas religiosas, del que es autor el mismo Joan Prat.

${ }^{6}$ Los gitanos españoles suman algo más de medio millón de individuos, de los cuales casi la mitad reside en Andalucía. Por provincias, y de modo semejante a lo que muestran los datos históricos del siglo XVIII, la mayor presencia corresponde a Sevilla, seguida de Granada y Cádiz (Gamella, 1996; Cantón et al., 2004). 
está atravesada por complejos procesos de interacción rutinaria con el mundo no gitano en los diversos contextos regionales, locales e institucionales, es un hecho que todavía continua lastrada por condiciones recurrentes de pobreza y exclusión, en ocasiones extremas, así como permanece sujeta al efecto provocado por la presencia de arraigados estereotipos xenófobos que persisten históricamente en el imaginario social. Hay que decirlo una vez y otra, si bien, a cambio de esta insistencia legítima porque nos deja visibilizar las carencias de un pueblo destituído, el precio sea a menudo reducir. Las representaciones armónicas y unificadoras de los sectores "marginados", que acaban presentándolos como un todo homogéneo en virtud de una posición común de subordinación que los unifica, trae algunas consecuencias indeseables: Reifican grupos étnicos y fronteras sociales, privilegian el abordaje dicotómico o dualista de la vida social olvidando que ésta sucede principalmente en el flujo y la interacción, así como desatienden por definición desde la experiencia social hasta las relaciones asimétricas de poder y desigualdad que se dan entre ellos. La subalternidad puede funcionar como una coartada, parece como si no hubiera otra vía para volver a los subalternos reconocibles como agentes históricos que reducirlos a su condición de víctimas. Volveremos sobre ello.

Pues bien, un factor decisivo ha venido a sacudir intensamente este escenario tan sucintamente esbozado, y sus impactos sobre la población gitana española han sido todavía poco explorados. Nos referimos a la irrupción del movimiento evangélico gitano. Su instancia más representativa en España es la Iglesia Filadelfia, de adscripción pentecostal. Durante los últimos años he venido analizando los usos políticos emergentes de esta modalidad de protestantismo, presente entre los gitanos españoles desde los años cincuenta del siglo XX y que ha producido en la última década novedosas narrativas de pertenencia e imaginarios de la marginación o la diáspora, muchas veces mediante la música - un pop evangélico a la vez globalizado y local一, pero también formas asociativas políticamente relevantes que están desempeñando un papel significativo en la autogestión de los procesos de cambio, en la puesta en marcha de nuevas estrategias de movilización étnica y de visibilización política de la minoría gitana, o en la producción de discursos religiosos y culturales legitimadores de cierta clase de acción política y simbólica.

Las primeras conversiones de gitanos al protestantismo tuvieron lugar en el occidente de Francia a mediados del siglo XX. Catalanes y vendimiadores temporeros, a su regreso a España, comenzaron a evangelizar primero entre gitanos de todo el norte español y más tarde el centro y este peninsular hasta alcanzar en los pasados años sesenta Andalucía occidental donde, aún bajo el régimen franquista, se organizaron las primeras reuniones evangélicas lideradas por gitanos. Desde sus orígenes se ha tratado de agrupaciones religiosas doctrinalmente emparentadas con aquellas que resultaron de la evolución del cristianismo reformado en los Estados Unidos, caracterizadas por conectar el ascetismo puritano y el sentimentalismo característicamente metodista, y que en las últimas décadas ha devenido uno de los más notables exponentes de globalización religiosa y cultural, con implicaciones políticas muy profundas (Freston, 2001). Entre los gitanos europeos, latinoamericanos y, en nuestro caso, españoles, se han multiplicado las apropiaciones en clave 
étnica y local de este pentecostalismo norteamericano. Es necesario hacer un alto en esta última circunstancia, porque se trata de un sistema religioso cuyos fundamentos teológicos, doctrinales y morales son siempre similares, cuando no simplemente idénticos, mientras las prácticas concretas dependen de contextos históricoculturales, así como de condicionantes socioeconómicos y políticos que explican las especificidades y resemantizaciones particulares en la apropiación de los sistemas religiosos. Por ejemplo, en comparación con los pentecostalismos latinoamericanos, en las organizaciones eclesiales y paraeclesiales gitanas españolas no ha cuajado el modelo canónico de organización política descentralizada y acéfala; por el contrario se mantiene una estructura excepcional de autoridad piramidal con un presidente que es elegido anualmente en una reunión de la Asamblea Nacional de la Iglesia Filadelfia. En cambio sí encontramos la misma práctica corporal carismática, los cultos extáticos y de posesión por el Espíritu Santo, en parte explicables por la influencia histórica del Gospel y de las prácticas rituales afroamericanas.

Pero lo que aquí nos interesa destacar es que en la última década el pentecostalismo gitano se ha vuelto un movimiento cada vez más orientado y estructurado políticamente. Esto es interesante porque los gitanos de todo el mundo han sido descritos como sociedades históricamente reacias a organizarse siguiendo modelos socio-políticos que trasciendan el grupo de parientes. Las relaciones políticas se han articulado a partir de la autoridad de los hombres adultos y los ancianos de prestigio, es decir, a partir de la lealtad a los vínculos de filiación. Pero es un hecho que en las últimas décadas este modelo acéfalo de las relaciones políticas, contrario a toda forma de centralidad e integración que vaya más allá de la lógica gerontocrática, los grupos domésticos y los linajes, ha ido cambiando y desde los años sesenta del XX han surgido otras formas de poder interno. Esas nuevas formas de poder interno, advertidas hace ya años por la antropóloga Teresa San Román, son el asociacionismo y el pentecostalismo gitanos, surgidos paralelamente a los procesos de sedentarización y urbanización de importantes sectores de la población gitana en España. (San Román, 1997).

El asociacionismo gitano no confesional ${ }^{7}$ ha corrido una suerte diversa, pero en todo caso marcada por su dependencia de las administraciones del Estado, las divisiones internas que han ido debilitándolo y las contradicciones debidas a la participación de gitanos en estructuras organizativas no gitanas. El caso del pentecostalismo es en cambio muy distinto, porque se ha ido extendiendo entre los gitanos de manera autónoma, con liderazgos, financiación y gestión propias y permaneciendo, hasta tiempos muy recientes, apartado de las subvenciones públicas y de los aparatos de poder administrativos.

Pero todo esto cambia a partir de la creación de la Federación de Asociaciones Culturales Cristianas de Andalucía (FACCA), una entidad que nace en 2001 a partir de la iniciativa de cuatro iglesias y que a comienzos de 2010 ya agrupaba

${ }^{7}$ No obstante, sus orígenes son también religiosos. El movimiento asociativo gitano, cuyos primeros pasos se dan en los años sesenta del siglo XX, se debió a una iniciativa de sectores no gitanos cercanos a la Iglesia Católica. Sólo a partir de la pasada década de los setenta comenzará la dirección de estas asociaciones a ser asumida por los gitanos. 
a más de ciento veinte iglesias convertidas en asociaciones culturales. En su mayoría se concentran en Jaén (Linares) y Córdoba y son el resultado de la paulatina transformación de aproximadamente un $10 \%$ de las iglesias protestantes gitanas de Andalucía en "asociaciones culturales cristianas" que trabajan "para mejorar la proyección social y cultural de la comunidad gitana en general" y se presentan, en la documentación interna que he manejado, como "acción social organizada" o como "el brazo social" de la Iglesia Filadelfia. Desde el momento de su fundación, la FACCA está proponiendo extender su modelo organizativo a otras autonomías ${ }^{8}$, promoviendo la transformación completa de las iglesias o cultos en entidades subvencionables - asociaciones-, explorando nuevas vías para favorecer el diálogo con las administraciones del Estado, conseguir recursos que financien un extenso programa de actividades formativas e impulsar la visibilidad política de la minoría? En 2003 fue declarada Institución de Utilidad Pública debido al reconocimiento a la labor que desarrolla y por representar en aquel año a unos diez mil gitanos pentecostales, a la que los dirigentes de la FACCA consideran que es su base social en Andalucía. En 2005 el presupuesto había pasado de los 9000 euros iniciales a 427.000. Nos haremos una idea de su cada vez mayor peso institucional si aclaramos que en 2010 la FACCA llegó a manejar dos millones de euros, lo que significa una acelerada captación de fondos en relación a su dotación presupuestaria a comienzos de la década. Es sabido que su proyección pública se vió muy favorecida en 2009 con el apoyo prestado por la FACCA en las campañas para esclarecer el asesinato de la niña gitana Mari Luz Cortés, un caso de extraordinario impacto mediático. El padre de Mari Luz Cortés es gitano y pastor evangélico en activo. En los últimos años la Iglesia Filadelfia de San Juan de Aznalfarache (Sevilla) se ha convertido en un verdadero centro de peregrinación para evangélicos gitanos y no gitanos que quieren conocer a Juan José Cortés, vuelto un símbolo.

Medio siglo de avance incesante ha convertido este movimiento socio-religioso y político en una de las más excepcionales experiencias organizativas puestas en marcha por los gitanos españoles ${ }^{10}$. La doble sospecha a la que estuvieron expuestos

${ }^{8} \mathrm{Y}$ en 2010 contaba con delegaciones en Baleares, Canarias o Cataluña. Más aún, las iglesias pentecostales gitanas de Bulgaria han solicitado en 2010 apoyo institucional a la FACCA andaluza para seguir su modelo organizativo.

${ }^{9}$ Entre los fines que FACCA destaca en su Memoria Anual se citan: "Potenciar el desarrollo cultural y social de los gitanos/gitanas; potenciar la creación de nuevas entidades de fines análogos a los de las asociaciones que constituyen esta Federación, y desarrollar y verterbrar la actuación conjunta de éstas; informar de todas las posibilidades del mercado de trabajo, en materia cultural, formativa, a través de concursos, talleres, becas, información en general : mejorar la proyección y formación de todos/as los gitanos/as en materia socio-cultural; participación en materia cultural, para la promoción y el desarrollo de la Iglesia Evangélica Cristiana; como fin prioritario apoyo a los drogadictos y delincuentes para su reinserción social; cooperar con países del Tercer Mundo o en Vías de Desarrollo, con especial incidencia en Europa y Latinoamérica".

${ }^{10}$ Ello no obsta para que Luís Guillermo Cortés, director técnico de la FACCA, lamente la "marginación institucional" que padecen y que él atribuye a la sistemática estigmatización de los ideales cristianos que la izquierda identifica con valores de la derecha política, lo que para una organización "sin cobertura política, porque somos apolíticos", sólo puede traer problemas (entrevista concedida en diciembre de 2010). 
los miembros de las iglesias desde sus comienzos, por ser parte de una minoría étnica estigmatizada y por nutrir una organización religiosa legal y reconocida, pero considerada sectaria por la mayoría social, ha marcado profundamente la elaboración del propio sentido de pertenencia etno-religiosa en las diversas comunidades gitanas. Pero, al mismo tiempo, también ha tenido su parte en el surgimiento de complejos procesos de etnogénesis y reinvención cultural, lo cual a su vez ha ido dando paso a la movilización intencional y dirigida de un cierto sentido de la etnicidad gitana, la puesta en marcha de políticas de identidad y la creciente actividad política de la FACCA en Andalucía. Esta actividad está orientada a impulsar el papel político de los gitanos evangélicos, a definir nuevos interlocutores con las administraciones del Estado y a la obtención de recursos públicos para financiar programas asistenciales y formativos que promuevan la inserción en el mercado laboral o impulsen políticas de igualdad, por ejemplo en materia de género o absentismo escolar. En este sentido cabe identificar los diversos programas de actividades puestos en marcha desde las agencias asociativas y federativas del pentecostalismo gitano: las de carácter formativo - talleres-, laborales —inserción en el mercado de trabajo-, de lucha contra las drogodependencias - información y tratamiento en centros de desintoxicación del policonsumo-, asistenciales, religiosas - formación teológica para líderes evangélicos-, políticas, socio-comunicacionales - presencia en los medios de comunicación, prensa y radio evangélicas, uso de las nuevas tecnologías de la información, música - y de intermediación ante las administraciones el Estado.

Los dirigentes de la Federación de Asociaciones Culturales Cristianas de Andalucía — si bien no es éste el único ejemplo de federación evangélica gitana en el conjunto del Estado ${ }^{11}$ — proclaman estar trabajando para extender su modelo de una manera paulatina y programada. La presencia en aumento de las federaciones culturales cristianas y la incorporación de miembros de las iglesias transformadas en asociaciones, que posteriormente se federan conformando una estructura de creciente complejidad burocrática, están convirtiendo a los agentes de culto y a los líderes asociativos en agentes mediadores que han pasado de ser "pastores de almas" a convertirse en "gestores de recursos", según afirman críticamente algunas voces desde dentro de las iglesias gitanas más veteranas. Esto último está provocando un proceso negociador sin precedentes entre la vieja guardia, constituída por los pioneros de la Iglesia Evangélica Filadelfia, sus líderes, responsables de zona, pastores y candidatos de prestigio por un lado, y las jóvenes generaciones de gitanos políticos vinculados a la FACCA, que tienen una visión "más moderna y actual, acorde con los tiempos pero sin abandonar los valores cristianos" - en palabras del director técnico de la FACCA - de lo que el evangelismo pentecostal gitano está llamado a liderar.

El trabajo de campo realizado en poblaciones gitanas de Andalucía occidental - Sevilla y Cádiz, principalmente- a finales de los pasados años noventa y primeros de la década siguiente nos dejó ver cómo los nuevos actores políticos, al menos

${ }^{11}$ Existen federaciones en las comunidades de Madrid y Cataluña. 
en nuestro área de trabajo, habían surgido en parte de la fuerza con la que la familia y los lazos primarios, las redes de parientes y la gerontocracia gitana, conforman todavía la organización social y articulan la solidaridad intragrupal entre los gitanos, al punto de llegar a reproducirse eventualmente en vínculos paralelos de carácter religioso. Los individuos que pasan a integrarse en las congregaciones evangélicas y protagonizan después esta renovación de las políticas étnicas son, por tanto, aquellos a los que, en principio, cabría presuponer una mayor integración en la sociedad dominante. Me estoy refiriendo a quienes, por ejemplo, participan regularmente en mercados ambulantes reglamentados por las entidades municipales, principal nicho ocupacional de las familias gitanas que integran las iglesias. Por tanto, el avance político del evangelismo gitano no se podría sostener partiendo del supuesto funcionalista de la desestructuración, la anomia, el empobrecimiento de las relaciones sociales o el deterioro de los vínculos de parentesco, premisas que parcialmente pueden explicar su surgimiento hace ya medio siglo, pero no su posterior evolución. Más bien cabe pensar en su contrario, es decir, en el eficaz funcionamiento de las redes de parientes. De hecho, son frecuentemente familias enteras las que pasan a integrar las iglesias locales, lo que revierte de modos diversos en la familia extensa o patrigrupo. Es interesante porque esto mismo contradice el carácter individualista moderno que se ha querido atribuir monótonamente a la religión pentecostal y que los análisis locales tantas veces desmienten $\mathrm{o}$, al menos, invitan a matizar. Todo ello no obsta para que, por otra parte y como ya se ha señalado, el pentecostalismo busque de algún modo poner en marcha "nuevas estructuras transversales diferentes a los grupos de parientes", que sean capaces de movilizar recursos y atención públicos (San Román, 1999). Son diferentes, pero no están enfrentadas.

Pero si es preciso correlacionar históricamente el surgimiento de la Iglesia Filadelfia con los procesos de sedentarización y urbanización que han afectado a la población gitana española en las últimas décadas, también lo es vincular la creación en 2001 y el posterior auge de la FACCA a un momento histórico particular, en el que el fenómeno de la inmigración masiva - hoy atenuado por la crisis económica- a comienzos de la década pasada estaba teniendo un impacto decisivo sobre la consideración pública de los problemas que afectan a la comunidad gitana. Ello ocurría mientras se registraba uno de los momentos más comprometidos del movimiento asociativo gitano no confesional. En este sentido, cabe postular una conexión significativa entre el declive relativo del asociacionismo gitano aconfesional y el auge de las federaciones culturales cristianas que siguen el modelo de la FACCA, esto es, debemos sopesar la medida en la que el desgaste del asociacionismo aconfesional ha podido beneficiar indirectamente la consideración del papel de la FACCA como interlocutor de prestigio ante las administraciones autonómicas del Estado, principalmente en Andalucía ${ }^{12}$.

${ }^{12}$ Sólo en Sevilla existe una Secretaría para la Comunidad Gitana, dependiente de la Consejería de Asuntos Sociales de la Junta de Andalucía. 
El proyecto de investigación en el que actualmente trabajo ${ }^{13}$ tiene como finalidad establecer el origen, la historia y distribución de las asociaciones y federaciones evangélicas, partiendo del caso concreto de la FACCA; investigar en detalle los procesos de formación del liderazgo político-religioso, el carisma y la agencia dentro de estas organizaciones para-eclesiales, así como el surgimiento de una agencia política en el seno de las estructuras asociativas y federativas religiosas gitanas; explorar etnográficamente, clasificar, tipificar y analizar la heterogeneidad interna de movimiento federativo pentecostal gitano en Andalucía, Madrid y Cataluña; explorar las narrativas etnopolíticas y los imaginarios de la diáspora elaborados en clave bíblica. El objetivo consiste en avanzar más allá de unos indicios significativos y abordar la formación y transmisión de un nuevo liderazgo asociativo y político con raíces religiosas protestantes entre los gitanos, cartografiar sus redes y estudiar las razones y los soportes discursivos de su creciente proyección política, tanto desde una perspectiva intraétnica como desde su contribución al diálogo interétnico e institucional. Esta indagación pasa por observar el lugar que ocupan los centros de culto y los agentes religiosos mediadores de la Iglesia Filadelfia — responsables de zona, pastores y candidatos - en la constitución de esta naciente elite política, así como los conflictos que esta suerte de autoridad paralela está generando en relación a la organización nacional y autonómica de la Iglesia Filadelfia. Para todo ello estoy tomando como eje el caso paradigmático FACCA.

Mi interés es ampliar la reflexión sobre las relaciones entre comunitarismo religioso evangélico, construcción étnica de la pertenencia y su vinculación con procesos políticos recientes, es decir, ilustrar desde este ángulo concreto la complejidad de la intersección entre religión y política en algunos de los lugares de la contemporaneidad menos transitados por las Ciencias Sociales. Es una preocupación clásica, por otro lado, desde al menos Max Weber. De manera secundaria, trato contribuir al conocimiento de las redes transcionales del pentecostalismo gitano, esto es, a comprender e ilustrar el surgimiento de una comunidad transnacional gitana o pangitana estructurada en torno a la pertenencia religiosa. En síntesis, me mueve el interés por analizar, desde una perspectiva socio-antropológica, los recientes usos políticos del evangelismo pentecostal gitano y las estrategias creativas de movilización étnica, de visibilización política y liderazgos nuevos en el seno de las estructuras para-eclesiales y federativas de la FACCA. Más allá de su rol de mediación con las administraciones del Estado y de promover el paso de la iglesia a la entidad administrativamente reconocible y, por tanto, subvencionable, estos nuevos líderes están cambiando el rumbo marcado por los fundadores de la Iglesia Filadelfia hace ya más de medio siglo. Todo ello pasa por la identificación de las federaciones y asociaciones cristianas existentes en España, por definir su vinculación más o menos conflictiva con las organizaciónes eclesiales evangélicas gitanas ya establecidas, con su estructura de autoridad central —Asamblea Nacional de la Iglesia Filadelfia,

${ }^{13}$ MICINN, Ref. CSO2010. El proyecto trianual, aprobado en 2010, se desarrollará entre los años 2011 y 2013 y cuenta con la colaboración excepcional, como parte del equipo de investigación, de la Dra. Teresa San Román Espinosa. 
con sede en Madrid - y a niveles locales — responsables de zona, pioneros de la obra, pastores y candidatos-; o por el mapeado de las congregaciones, las instancias asociativas vinculadas y su proyección política a partir de las federaciones cristianas.

Para ello trato de definir algunas hipótesis. Como ya ha quedado expuesto, la Federación de Asociaciones Culturales Cristianas de Andalucía, si bien no es el único ejemplo de este tipo de organización evangélica gitana en el conjunto del Estado, sí que está extendiendo de una manera intencional y programada su modelo federativo, compuesto de iglesias evangélicas transformadas en asociaciones. La presencia en aumento de federaciones culturales, dotadas de una estructura de creciente complejidad burocrática, está consolidando a una parte de los antiguos pastores de los cultos y a los líderes asociativos como mediadores para la inserción laboral, la gestión de nuevas ayudas económicas, la formación ocupacional, la promoción de la cultura gitana - resignificada desde una perspectiva evangélica- y la puesta en marcha de actividades destinadas a ganar presencia como minoría con capacidad política. Ello está derivando en un proceso negociador nuevo entre los propósitos y valores defendidos por la vieja guardia del movimiento pentecostal gitano, constituída por los pioneros de la Iglesia Evangélica Filadelfia, sus líderes, responsables de zona y pastores de prestigio por un lado, y las jóvenes generaciones de gitanos políticos impulsados por nuevos ideales y vinculados en gran número a la FACCA, que tienen una visión más orientada políticamente y atenta a las oportunidades del mercado, menos purista y conservadora, de lo que el evangelismo pentecostal gitano debería aportar a "la comunidad" en el siglo XXI. Se trataría de un exponente de esa relación cambiante entre cultura y mercado que John y Jean Comaroff despliegan en la exploración transcultural de su último libro (Comaroff, 2009), en el que postulan que la categoría etnicidad, siempre borrosa y equívoca como concepto sociológico, se estaría transformando en la dirección opuesta a la que apuntaban las ciencias sociales ortodoxas. Están cambiando la etnopolítica, las etnoprácticas, la etnoconciencia y nuestro mismo modo de aprehender todo ello como científicos sociales.

Contextos muy diversos de hegemonía religiosa católica, como es el caso de España y de Andalucía, se encuentran desde hace algunas décadas inmersos en rápidos procesos de cambio hacia una mayor pluralidad y heterogeneidad de la oferta religiosa, a lo que contribuye de manera decisiva la movilidad transnacional contemporánea y, desde luego, el despliegue de nuevas organizaciones religiosas en los extensos conglomerados urbanos. Los estudios sobre reterritorialización, inmigración, fronteras, transferencias, glocalización y transnacionalismos se han multiplicado en la última década, paralelamente a la intensificación de los flujos migratorios y de los procesos de empowerment protagonizados por comunidades étnicas que muestran la cada vez más compleja relación entre las organizaciones religiosas locales y sus características estructuras de acogida, de un lado, y la realidad política de las minorías étnicas, del otro. El caso que trato aquí es distinto y de naturaleza centrípeta, en tanto los gitanos constituyen la principal minoría étnica del Estado español cuya presencia se remonta siglos atrás. Pero, al mismo tiempo, están protagonizando una transformación cultural, simbólica y política, con origen en las 
conversiones religiosas protestantes, de tal dinamismo que cabe considerar la progresiva formación de una comunidad transnacional evangélica gitana estructurada en torno a la pertenencia étnica y religiosa. De ahí, el interés por explorar de manera comparativa y multisituada las distintas instancias y redes del pentecostalismo gitano en los niveles autonómico - Andalucía, Madrid y Cataluña-, nacional y transnacional. En Europa voy abordando, todavía de un modo tentativo, la presencia de formas políticas innovadoras en las iglesias gitanas, principalmente a través de una red de contactos en Alemania, Bulgaria, Rumania, Francia, Italia; en América Latina destaco las iniciativas políticas aún embrionarias del pentecostalismo gitano en México, Brasil, Colombia o Argentina.

Aunque todavía sin suficiente trabajo de campo etnográfico ad hoc, esta investigación está secundariamente encaminada a indagar el surgimiento de una comunidad transnacional emergente de gitanos evangélicos. No en vano autores como P. Williams han sostenido que, represente el éxito del pentecostalismo el anuncio de una asimilación inminente o el signo de un reforzamiento de la autonomía de los gitanos, lo cierto es que la mayor novedad sociológica que introduce es la existencia a nivel global de los Tsiganes. Aunque también constituye una posibilidad de apertura hacia los no gitanos, el pentecostalismo significa sobre todo una apertura de las comunidades gitanas entre sí. En las grandes reencuentras - reuniones multitudinarias y periódicas de grandes iglesias evangélicas - podemos encontrar Manouches, Rom, Yéniches, Gitans... proclamando todos su irreductible hermandad (Williams, 1991).

\section{La construcción política del catolicismo indígena}

Desde la primera mitad del siglo XX, Chiapas - y más concretamente la región de Los Altos- ha representado un lugar privilegiado para llevar a cabo estudios orientados por distintas líneas teóricas. El relativo aislamiento geográfico resultado de la abrupta y compleja orografía del territorio, combinado con la persistencia de una cuantiosa población indígena que aún hablaba sus lenguas de raíz maya, evocaban la idea de la supervivencia de una cultura prehispánica prácticamente incontaminada, a la vez que ponían de manifiesto lo que después sería considerado como el problema indígena en medio de un México que se pretendía moderno. La búsqueda de culturas indígenas genuinas atrajo, durante las pasadas décadas de los cincuenta a los setenta, a nutridos grupos de antropólogos culturalistas ${ }^{14}$, quienes mediante la realización de numerosas etnografías, acababan por confirmar que, efectivamente, las identidades étnicas permanecían estables en el tiempo - al sostenerse sobre un equilibrio imperturbable que despejaba toda sombra de conflicto en el interior de las poblaciones y entre ellas - y que, además, se encontraban perfectamente definidas por las, al parecer, impermeables fronteras de la comunidad ${ }^{15}$. Paralelamente, desde la antropología mexicana se manifiesta el interés por conocer al indigena pero con

\footnotetext{
${ }^{14}$ Destacan los procedentes de las universidades de Chicago - a cargo de Norman McQuowm y Julian Pitt-Rivers - y de Harvard — bajo la dirección de Evon Vogt-.

${ }^{15}$ La profusión de estudios de comunidad, llevados a cabo en México, consiguió que se asumiera a la comunidad como la unidad territorial, cultural y social más apropiada en tanto referencia de ob-
} 
otro propósito: el de integrarlo en la sociedad nacional y rescatarlo de la situación de atraso en la que, según se consideraba, estaba sumida esa población. Así, se impulsaron investigaciones que, teniendo también a la comunidad como eje, estuvieron encaminadas a descubrir los aspectos culturales que obstaculizaban su desarrollo económico, condenaban a los indígenas a una marginación y a una pobreza seculares y les impedían su completa integración en la modernidad ${ }^{16}$. Posteriormente, la comunidad dejó de ser la destinataria preferente de los programas indigenistas, para ser sustituida por la región intercultural y la región de refugio ${ }^{17}$. En definitiva, la población indígena había sido caracterizada como reticente al cambio, cerrada, estática y arcaica $^{18}$. Como consecuencia de la conjunción de tales rasgos, las comunidades indígenas acaban quedando representadas, casi en exclusiva, por sus poderosas formas de integración; o dicho de otro modo, por la potente fuerza centrípeta de la que hacen gala los distintos mecanismos de adscripción - sea familiar, religiosa, étnica o territorial—, que, en suma, daban pie a generar imágenes de sociedades con una identidad fuertemente consolidada e impenetrable a las influencias externas.

No obstante, a partir de los últimos años setenta y, especialmente, en los ochenta, el interés por la estabilidad y el equilibrio, en tanto carácterísticas esenciales de las poblaciones indígenas, es deplazado por la atención a los procesos de cambio mediante estudios que, dejando atrás las imágenes de un presente etnográfico, se deslizan en los vericuetos históricos con el propósito de comprender las transformaciones de diversa índole — política, económica, religiosa...- que también

servación e, incluso, yendo más allá, que fuese aceptada como el fundamento desde el que definir lo indigena.

${ }^{16} \mathrm{Si}$ bien estas ideas indigenistas estaban aplicándose desde los pasados años 20, a través de las Misiones Culturales, no será hasta 1940 — con la celebración del Congreso de Pátzcuaro- cuando el indigenismo se reconoció institucionalmente. Dichas Misiones Culturales estaban promovidas por la Secretaría de Educación Pública, siguiendo el modelo de una educación transformadora, capacitadora e integradora del indígena (Korsbaek y Sámano, 2007: 202). La puesta en práctica de las ideas indigenistas que, en principio, se movían entre el asimilacionismo y el integracionismo, era tarea del Instituto Nacional Indigenista (INI), y tal aplicación se hacía a través de los Centros Coordinadores repartidos por todo el país. El primero de esos Centros se inauguró en la ciudad de San Cristóbal de Las Casas (Chiapas) en 1951, bajo la dirección del antropólogo mexicano Gonzalo Aguirre Beltrán.

${ }^{17}$ De este modo, se amplían los límites territoriales para pasar a tener en cuenta no sólo el espacio en el que interactúan mestizos e indígenas, esto es, la región intercultural, sino fundamentalmente el hinterland que se dispone alrededor de la ciudad rectora, compuesto por un número determinado de comunidades y que constituye las regiones de refugio. Éstas son definidas como zonas marginadas, habitadas sólo por indígenas que se encuentran en situación de subsistencia y que, además de practicar culturas distintas a la nacional, están sujetos a la explotación de grupos sociales más avanzados. Al vivir prácticamente enclaustrados en sus territorios, mantienen sus patrones de conducta y sus valores y, por ello, se muestran reacios a cualquier alternativa de transformación (Aguirre Beltrán, 1987).

${ }^{18}$ Así, por poner algunos ejemplos, Foster (1976), a través de su imagen del bien limitado, explica el carácter conservador que les hace tan reacios a aceptar las ventajas que les ofrecen los cambios; Wolf (1981), al hablar de comunidad corporativa cerrada, se refiere a una sociedad hermética, con límites claramente definidos, tanto desde dentro como desde fuera, y cuya identidad se mantiene a pesar del transcurso del tiempo Aguirre Beltrán (1987), como se ha visto más arriba, si bien amplía los límites comunitarios a los de las regiones de refugio, sigue esa misma línea y, con ello, se mantiene en la idea de la esencia étnica. 
experimentan las sociedades indígenas. Esos estudios ponen en entredicho la naturaleza equilibrada e igualitaria de las relaciones sociales, a la vez que profundizan en el análisis de los conflictos que han ido jalonando la historia indígena en México $y$, más concretamente, en Chiapas ${ }^{19}$. A partir del levantamiento zapatista (1994) se desata una corriente de simpatía hacia la rebelión indígena, teñida de inocultables evocaciones románticas. Una de las consecuecias de este movimiento de admiración por todo lo indigena - como depositario de lo auténticamente humano - fue que en la mayoría de las investigaciones realizadas en esos años, se produjera un retorno a la utilización de la imagen homogeneizadora de las distintas poblaciones indígenas basándose, para ello, en la consideración de que existe una subordinación compartida por todas ellas. Se deduce, pues, que esa participación en una categoría subordinada, que les es común, no sólo les conduce sino que, sobre todo, les reduce a una inevitable y pasiva condición de víctimas. Asimismo, una parte significativa de estos nuevos estudios ha querido recuperar la idea de la armonía como representación clave de estas sociedades, ensombreciendo las asimetrías y las desigualdades presentes en el seno de las propias comunidades y relaciones intraétnicas.

No es éste el momento de hacer un recorrido por la historia de las diversas etnias que habitan en Chiapas, pero sí puede comentarse que a lo largo de la línea temporal que llega hasta el presente, para hacer frente a una serie de factores y agentes externos, las identidades indígenas han ido conociendo grietas y escisiones que han obligado a estas poblaciones a llevar a cabo una serie de reajustes, renovaciones e, incluso, reinvenciones. Uno de esos agentes externos ha sido la iglesia católica y, con ella, su modo de intervenir y adecuarse a la vida social de las comunidades indígenas. Lejos de mantenerse en la actitud de pasividad e, incluso, de victimismo que se les ha querido atribuir, los indígenas han hecho uso de los recursos y oportunidades que ha supuesto dicha intervención eclesiástica para establecer una estrategia de movilización política, mediante la legitimación que los discursos religiosos les han proporcionado. Si hubiera que localizar el inicio de esa estrategia, habría que fijarse en las actuaciones vinculadas con la aplicación de las directrices nacidas en la Conferencia Episcopal de Medellín (1968) ${ }^{20}$. Según esas directrices, la iglesia

\footnotetext{
${ }^{19}$ Uno de los conflictos más llamativos durante los pasados años setenta y ochenta —y que aún persiste- es la expulsión de miles de indígenas de sus comunidades por aparentes motivos religiosos. Esas expulsiones se inauguraron en el pueblo tztoztil de San Juan Chamula cuando, en primer lugar, quienes abrazaron el catolicismo liberacionista y, posteriormente, los que se adscribieron a distintas denominaciones protestantes hicieron frente a las normas impuestas por las autoridades tradicionales, practicantes del catolicismo de la costumbre. Negarse a consumir alcohol, a comprar cohetes o velas, por ejemplo, significaba una afrenta a las tradiciones y la autoridad de los principales, así como un menoscabo que afectaba al comercio de estos productos, cuyo control estaba en manos de dichas autoridades. Ser expulsado de la comunidad significaba, además, perder todo tipo de derechos de posesión y propiedad sobre bienes muebles e inmuebles. Tras Chamula, otras comunidades de Los Altos también han protagonizado este tipo de expulsiones. Una parte sustancial de estos expulsados se ha establecido en la periferia de la ciudad de San Cristóbal de Las Casas.

${ }^{20}$ Esta Conferencia se celebró en un agitado escenario político — aplicación del desarrollismo (Alianza para el Progreso); imposición de dictaduras militares; movimientos guerrilleros; reciente revolución cubana - que llevó al obispado, al clero y al laicado más activo a desplazarse hacia la izquierda política: acompañaron a los movimientos sociales de raíz proletaria, campesina y estudiantil
} 
debe impulsar y animar la organización de grupos que desencadenen un proceso asociativo, con el fin de reivindicar el respeto a los derechos de la población pobre y oprimida. Conseguir un nuevo modelo de relaciones sociales, económicas y políticas es tarea tanto de los laicos como de la iglesia institucional; una tarea que consiste en proponer un desarrollo humano basado en la justicia y la solidaridad. En concordancia con estos planteamientos, la iglesia debe ser la primera en aceptar que los pobres y marginados son sujetos y protagonistas de su propia historia. De este modo, los teólogos liberacionistas ofrecen su apoyo a las Comunidades Eclesiales de Base - CEB - , que se estaban constituyendo por iniciativa de los laicos. La lectura crítica de la Biblia se convierte en el punto de partida desde el que las CEB reflexionan sobre el lugar que ocupa la iglesia católica en Latinoamérica, así como sobre sus vínculos con los poderes establecidos, a la vez que se cuestiona críticamente sobre la actitud, tanto de la institución como de los laicos, hacia la pobreza y quienes viven en ella.

Las CEB pueden interpretarse como el reflejo de la voluntad de los laicos de no reducirse a ser meros receptores de una evangelización eminentemente sacramentalista. Son, por tanto, una evidencia de la madurez social alcanzada por quienes se muestran capaces de integrar grupos que hagan posible la participación activa y la libre expresión, como orientaciones claves de la vida comunitaria imaginada. Asimismo, entre las CEB más experimentadas, la práctica constante de una dinámica de discusión, intercambio de opiniones e ideas, experiencia organizativa y de lucha deriva en la asunción de un deseo de autonomía y en el cuestionamiento del orden social - y eclesiástico - , todo lo cual acaba desencadenando un proceso paulatino y consciente de empoderamiento. En suma, la mayoría de estas comunidades acaban adquiriendo un consecuente tinte político, al percibirse a sí mismas como uno de los escasos espacios sociales - en países con exiguas libertades constitucionalesdonde el fenómeno asociativo puede sobrevivir con cierta salvaguarda - al estar bajo el paraguas de la iglesia- y en el que, además, el discurso religioso se ve desbordado por la cuestión social.

La Diócesis de San Cristóbal de Las Casas abarca casi la mitad del territorio estado de Chiapas ${ }^{21}$. Un porcentaje significativo de su población —-más del $60 \%$ - es de raigambre indígena distribuida en cuatro etnias mayoritarias: tzotzil, tzeltal, ch'ol y tojolabal; y otras minoritarias: chuj, mam, kanjobal, lacandón y zoque. Esa población es, además, la que se encuentra engrosando las estadísticas en los mayores índices de pobreza del estado: en términos generales, ser indígena en Chiapas significa

\footnotetext{
y asumieron la doctrina pedagógica de Freire, orientada a la liberación y concienciación de los grupos sociales oprimidos. Asimismo, el sector más crítico abogó por el conocimiento científico de las causas y factores que construyen el triángulo subdesarrollo-represión-miseria, con el propósito de llevar a cabo la denuncia del mismo. Para ello, no dudaron en utilizar la información ofrecida por las Ciencias Sociales.

${ }^{21}$ Actualmente, en Chiapas coexisten tres Diócesis: San Cristóbal de Las Casas, Tuxtla y Tapachula. La circunscripción diocesana ha experimentado múltiples ajustes territoriales a lo largo de su historia. En sus inicios, la superficie de la Diócesis - cuyo primer obispo fue Fray Bartolomé de las Casas- superaba los límites del actual estado chiapaneco. En 1958, se desgajó la Diócesis de Tapachula y unos años más tarde, en 1964, la de Tuxtla Gutiérrez.
} 
ser pobre ${ }^{22}$. No extraña por ello que el epítome liberacionista de la opción por los pobres, en el caso chiapaneco sea identificado con el de la opción por los indígenas. Y un reflejo de ello es la sustitución de la parroquia — como unidad de organización de la feligresía fundamentada en un criterio meramente territorial- por la zona o equipo pastoral siguiendo un criterio étnico-lingüístico ${ }^{23}$.

El obispo de la diócesis sancristobalense, Mons. Ruiz García ${ }^{24}$, participó en la Conferencia de Medellín y eso se tradujo en un sensible cambio, tanto en sus planteamientos teológicos como en el modo en que había desenvuelto su acción pastoral. La puesta en marcha de ese cambio llegó cuando decidió conocer a toda la población diocesana y, para ello, inició sus desplazamientos a las zonas campesinas e indígenas. Las tendencias inauguradas en Medellín supusieron que tanto él como los sacerdotes y religiosas más afines fueran paulatinamente alejándose de la actitud condescendiente y del paternalismo que impregnaban sus prácticas pastorales. Quizás, el reflejo más claro de ese cambio de tendencia fue el respaldo prestado a la celebración, en 1974, del Primer Congreso Indígena. Si bien la convocatoria fue realizada por el gobierno del estado, los indígenas lograron eludir su control y, a cambio, consiguieron el apoyo de la iglesia, puesto que propugnó siempre porque el congreso fuera de indigenas, favoreciendo la movilización sin presiones y la libertad de expresión (González Esponda, 1992:170) Los asistentes, llegados de toda la Diócesis, hicieron del Congreso un foro en el que expresaron, por una parte, sus demandas en asuntos como la tierra, el comercio, la salud y la educación; y, por otra, las denuncias de los atropellos que les infligían tanto el gobierno y los funcionarios, como los comerciantes y terratenientes. Asimismo, empujaron a la iglesia católica a definir más claramente su posición. En ese momento, salieron a la superficie las diferencias preexistentes en el interior de la institución: el sector más conservador

\footnotetext{
${ }^{22}$ Según el Consejo Nacional de Población (CONAPO), desde el año 2000, Chiapas ocupa el segundo lugar, a nivel nacional, con mayor grado de marginación. Como se expone en su último informe, correspondiente a 2005, dentro de Chiapas, los municipios de la región de Los Altos —eminentemente indígena - son los que registran los más elevados índices de marginación. Para llegar a estas conclusiones, CONAPO tiene en cuenta los porcentajes de la población que no participa del disfrute de bienes y servicios esenciales para el desarrollo de sus capacidades básicas (Anzaldo y Prado, 2006:11).

${ }^{23}$ La Diócesis de San Cristóbal de Las Casas está dividida en siete zonas: Ch'ol, Tzeltal, Tzotizl, Chab, Centro, Sur y Sureste. Las tres primeras corresponden a los grupos étnicos que las nombran y ocupan las regiones de Los Altos, la Selva Lacandona y el Norte. La zona Chab es un acrónimo de tres localidades - Chilón, Arenas y Bachajón — de población tzeltal y se encuentra bajo la responsabilidad exclusiva de los jesuitas. La zona Centro - donde se ubica la sede de la Diócesis - es básicamente mestiza, aunque va en incremento la población indígena desplazada en la periferia de la ciudad de San Cristóbal de Las Casas. La zona Sur también es de mayoría mestiza, pero cuenta con núcleos de tztotziles expulsados de sus lugares de origen. Finalmente, la población de la zona Sureste es básicamente tojolabal, si bien existen minorías de otras etnias mayenses procedentes de Guatemala. La Asamblea Diocesana constituye el máximo órgano de decisión y poder y congrega anualmente a todos los representantes zonales. La Asamblea delega en el Consejo Diocesano -instancia que se reúne mensualmente- la supervisión de los trabajos realizados por los distintos comités — análisis de la realidad, prensa...-.

${ }^{24}$ Monseñor Ruiz fue obispo de la Diócesis de San Cristóbal de Las Casas desde 1959 a 2000.
} 
manifestó su rechazo a la politización del Congreso, en tanto que los más proclives a los indígenas, encabezados por el propio obispo, aceptaron el reto propuesto.

Tanto los requerimientos presentados por los indígenas como la aceptación de los postulados liberacionistas extraídos de la Conferencia de Medellín contribuyeron a remodelar la práctica pastoral, de manera que fuera destinada exclusivamente a los indígenas. No obstante, puede identificarse otro antecedente de la misma en las críticas elaboradas por un grupo de antropólogos, que se encuentran compiladas en la Primera Declaración de Barbados (1971). El documento resalta el carácter hostil que la iglesia católica había venido mostrando hacia las culturas indígenas y propone a la institución que no siguiera haciendo de la actividad misionera un instrumento de colonización y dominio, que abandonara la actitud etnocida y que respetara los códigos culturales indígenas. No obstante, estos antropólogos reconocen que algunas tendencias católicas, en disensión con los mandatos jerárquicos, presentan una conveniente autocrítica (VV. AA., 1975: 24-27). Sin embargo, dos décadas después, el cambio de enfoque seguía siendo cosa de una minoría —en la que puede incluirse a la Diócesis de San Cristóbal—, como queda recogido en la Tercera Declaración de Barbados:

Reconocemos la transformación operada en la corriente progresista de la Iglesia Católica que, en los últimos veinte años, ha intentado reformular la práctica eclesiástica a partir del respeto a las religiones indígenas. Sin embargo, sectores mayoritarios de esta institución continúan ejerciendo un papel hegemónico que atenta contra los valores y culturas indias (VV. AA., 1994: 45).

Esta nueva pastoral muestra un proceso de transformación en los planteamientos evangelizadores que traza un continuum indigenismo-indianismo ${ }^{25}$. Antes de la celebración de la Conferencia Episcopal de Puebla $(1979)^{26}$, la pastoral podría

${ }^{25}$ Esa transformación es semejante al proceso experimentado por las instancias gubernamentales y por los círculos intelectuales respecto a su concepción sobre los pueblos indígenas. Pueden distinguirse dos grandes etapas. La primera de ellas se inicia en 1940 con la celebración del Congreso de Pátzcuaro (México) y durará tres décadas. En ese tiempo, el término clave es el de integración. Todas las políticas estuvieron orientadas por el objetivo de modernizar a los pueblos indios, para lo cual debían aceptar la asimilación que les llevara a su inserción en la cultura hegemónica. Esa integración suponía el desprecio por sus códigos culturales — que sólo serían empleados cuando tuvieran una utilidad folklórica-. El indio tenía que dejar de serlo para convertirse en ciudadano. Esa etapa de identidad indígena administrada por no indígenas fue conocida como indigenismo. La segunda fase comenzó en los últimos años setenta y arranca con la Primera Declaración de Barbados (1971). En ella, la corriente crítica de la Antropología puso en tela de juicio la política indigenista y exigió a los estados que garantizaran el derecho de ser, que poseen las distintas etnias. También se exigió que se reconociera el derecho a sus territorios y a la organización propia. Empezaba a hablarse de autonomía y autodeterminación. Esta etapa en la que el proceso identitario estaría en manos de los propios indígenas, con colaboración de no-indígenas, se conoció como indianismo.

${ }^{26} \mathrm{La}$ acción eclesial definida en Puebla tenía como propósito diseñar un proyecto alternativo a la modernidad caracterizada por una amenazante tendencia a la secularización. La institución busca expandirse entre la feligresía, entendida como pueblo y no como clase; de ahí su promoción de términos como cultura popular o religión popular, y el interés por reforzar los aspectos de ambas -ritos, ceremonias, tradiciones...- que pudieran contrarrestar el avance de la modernidad secularizadora. El 
calificarse como indigenista. En ese momento, el comportamiento más característico era el seguido según las pautas de Acción Católica, esto es, estaba orientado a la destrucción de la simbología y las ceremonias indígenas, con el fin de integrar a las distintas etnias en la ortodoxia católica. Sin embargo, la obstinación de la corriente más progresista logró que, a partir de Puebla, las líneas pastorales comenzaran a experimentar importantes modificaciones; para empezar, la propia denominación: la Pastoral Indigenista pasó a llamarse Pastoral Indígena y quedó estrechamente ligada a la Teología India. No obstante, andando el tiempo, ésta última versión sólo se llevará a la práctica dentro de los sectores minoritarios que siguen siendo afectos al liberacionismo, entre ellos, la propia diócesis chiapaneca.

El término clave de esta nueva tendencia es el de inculturación. Esa inculturación tiene una doble vertiente. Por una parte, viene a significar la encarnación del Evangelio en las culturas, es decir, el destierro de todos los ropajes occidentales - conductas, actitudes, valores, lógicas de pensamiento y de análisis - que pretendan anular las formas culturales autóctonas. Por otro lado, se convierte en requisito indispensable que los agentes de pastoral — sacerdotes, religiosos y religiosas - conozcan a fondo y de primera mano las condiciones de vida de los indígenas y que, paralelamente, acepten que el Dios cristiano también está presente en el seno de las poblaciones indias y debe ser descubierto en clave cultural indígena. Tal inculturación deberá conducir a la constitución de una iglesia autóctona, con personalidad propia según cada grupo étnico. Tal iglesia irá teniendo, a partir de lo que las comunidades decidan, su propia organización pastoral, su liturgia y sus ceremonias adaptadas a sus referentes y códigos culturales concretos. El mejor ejemplo de ese proceso de inculturación lo constituye la creación de un cuerpo de ministerios pastorales desempeñados por indígenas. Ese cuerpo, creado a instancias de los propios indígenas católicos, tiene como misión lograr que la institución acepte y asuma los ritos, mitos, símbolos y valores autóctonos. Es, por ello, el modo en que los indígenas están pasando a convertirse en los sujetos activos de su propia evangelización y, por tanto, en quienes acuerdan cómo debe desarrollarse esa praxis pastoral. Esta nueva iglesia entiende que la institución católica debe dar un paso más allá, apoyando y estimulando los distintos procesos sociales iniciados y protagonizados por la población india.

En el caso de la Diócesis de San Cristóbal de Las Casas (Gil Tébar, 1999b), esa evolución pastoral tiene sus raíces en el movimiento catequístico nacido en la pasada década de los sesenta; momento en que se fundaron las primeras escuelas

enfoque cultural — popular - proporcionado por la jerarquía, sin embargo, sirvió como revulsivo para que los teólogos liberacionistas y el clero más crítico asumieran esta perspectiva cultural, pero asimilándola a las diversas etnias que viven en Latinoamérica y que, hasta ese momento, habían desatendido —al incluirlas, homogeneizándolas, dentro de la categoría de pobres-. Ese giro quedó plasmado en la Conferencia Episcopal de Santo Domingo (1992). En ella, la presión ejercida por el grupo minoritario, que estaba practicando una política de acercamiento a las culturas indígenas, tuvo como resultado que, a pesar del conservadurismo instalado en el episcopado latinoamericano, se aceptara una nueva concepción de la población indígena; de modo, que ya no fuera reducida a la expresión amorfa de los pobres entre los pobres, sino que fuese considerada como grupo con identidad propia. 
de catequesis en las ciudades de San Cristóbal, Comitán y Bachajón. En ellas se capacitaron catequistas cuya formación acabó siendo el origen de muchos conflictos en el interior de las comunidades indígenas. El primer motivo de conflicto residió en el modo en que se reclutaron a quienes serían formados como catequistas. El proceso de selección estuvo en manos de los agentes de pastoral — sacerdotes y religiosas-, quienes no tuvieron en cuenta la opinión de las poblaciones de origen provocando el malestar, especialmente, de las autoridades tradicionales al ver cómo les era arrebatada su capacidad de decisión. Otra causa de conflicto fue el tipo de instrucción empleada en las escuelas catequísticas. Se trataba de un sistema docente vertical y autoritario, que se basaba en el método de la memorización mecánica de conceptos abstractos y con constantes alusiones a la teología occidental. En cuanto a la formación, encaminada a hacer del catequista un sujeto útil en su comunidad, estaba impregnada del inmediatismo y del asistencialismo propios de esa época desarrollista.

Una vez adquiridos todos los conocimientos necesarios en la ciudad, esto es, fuera de su contexto cotidiano - indígena y rural - los ya titulados como catequistas regresaban a sus comunidades, con el prestigio que les proporcionaba ser considerados hombres educados — una educación urbana y mestiza-. En ese retorno a sus orígenes fue cuando surgieron las más amargas consecuencias de la identificación entre evangelización y occidentalización que, durante todo el proceso formativo, se les había inculcado. Estos catequistas habían asimilado que, para evangelizar convenientemente a sus paisanos —un acto de poder, en sí-, tendrían que asumir como tarea prioritaria la destrucción de sus bases culturales, puesto que habían asimilado la premisa de la incompatibilidad entre la fe cristiana y las expresiones religiosas autóctonas. Los catequistas, en tanto convencidos agentes modernizadores, sentían la necesidad de sacar a sus poblaciones de la oscuridad de sus tradiciones. Según era de esperar, la colisión más fuerte tendría que ver con la confrontación entre catequistas y autoridades tradicionales a la hora de medir sus respectivas influencias, y al contrastar las disparidades entre unos y otros en los modos de adquisición de poder: frente al interminable camino de años que debían recorrer y a las onerosas cargas económicas que debían aceptar los hombres que serían reconocidos como autoridades, los catequistas en apenas unos meses, habían aprendido a leer y a escribir, además de haber obtenido una base de conocimientos que los convertían en jóvenes letrados. Por todo ello - desde la lógica occidental que habían interiorizado - estos hombres, a pesar de su juventud, se sentían competentes para poner en duda la capacidad de representación de las ancianas autoridades comunitarias. No se presentaba fácil la idea de mantener simultáneamente dos líneas paralelas - alternativas - de poder en el interior de las comunidades.

Finalizados los pasados años setenta, esta pastoral experimentó sensibles modificaciones en su trayectoria. Entre otros factores, fueron dos los más relevantes en tanto impulsores de ese cambio: la ya mencionada celebración del Congreso Indígena (1974) — cuyas críticas también recaían sobre la propia iglesia—y el fa- 
tigoso proceso de colonización de la Selva Lacandona ${ }^{27}$. Fueron varios los agentes de pastoral que acompañaron a los indígenas en su búsqueda de tierras en el interior del territorio selvático, ante la falta de terrenos en sus zonas originarias y ante el despido masivo de las fincas donde habían trabajado durante largos años. Adentrarse en la selva fue un proceso recordado por su crudeza, si bien, por otra parte, fue asimilado al Éxodo bíblico identificando a la Lacandona como una tierra de promisión. En estas nuevas circunstancias, los agentes de pastoral pudieron comprobar que la catequesis escolástica —occidentalizante - había perdido su aplicación y fueron ellos los primeros en evitar las prácticas aculturadoras, para iniciar el proceso inverso de encarnación en las culturas: nace así la que sería conocida como catequesis del Éxodo ${ }^{28}$.

Con esta nueva catequesis, se abrió paso a la participación activa y crítica de los creyentes, en general, en los encuentros pastorales y empezó a diluirse la relación de poder maestro-alumno que, hasta entonces, definía la comunicación entre el catequista y la comunidad. En este sentido, cabe destacar que desde este momento el catequista sería elegido por la comunidad de acuerdo a sus dotes como servidor de la misma, es decir, serían seleccionados aquellos que descollaran por su afán en el bien colectivo y por su capacidad para apoyar y orientar. Asimismo, el catequista fue desprendiéndose de su función docente y la comunidad fue abandonando su actitud pasiva como mera receptora. La nueva función del catequista era la de cuestionar e interpelar a la comunidad para que diese su palabra y reflexionara críticamente sobre su entorno religioso, social, económico y político. Una de las consecuencias de mayor calado, nacida de ese nuevo modo de trabajar, fue la contribución al nacimiento de una conciencia compartida que traspasara las fronteras de las comunidades y se ampliara a todas las zonas indígenas de la Diócesis. A través de las ceremonias religiosas y la lectura crítica de la Biblia, los indígenas se reconocen a sí mismos como sujetos con derechos - a través de la revelación de su dignidad-y como portadores de una cultura valiosa, esto es, se descubren como actores capaces de definir su propio destino.

El nuevo modo de ser catequista llevaba consigo la necesidad de recomponer las relaciones rotas con las autoridades tradicionales. Tal recomposición supuso que la palabra antigua de los ancianos fuese tenida en cuenta e incorporada en el proceso

${ }^{27}$ La colonización de la Selva Lacandona comenzó en la pasada década de los años cuarenta $\mathrm{y}$, en varias oleadas, se prolongó hasta los setenta. Fueron varias las causas que empujaron a miles de indígenas a abandonar sus comunidades para adentrarse en el terreno selvático: acelerada erosión y empobrecimiento de los suelos, crecimiento demográfico, inexistencia de alternativas económicas, expulsión de sus trabajos en las fincas, etc.

${ }^{28}$ En ese éxodo a la Selva Lacandona, los indígenas procedentes de distintas etnias y zonas de Chiapas adquieren conciencia de sus similitudes y, por tanto, consiguen traspasar las fronteras comunitarias que limitaban sus identidades a sus aldeas, para elaborar otra identidad más amplia e incluyente. No es de extrañar, pues, que en la Selva, tras haber compartido ese éxodo, se originaran algunas de las organizaciones indígenas más consolidadas. Las referencias al Éxodo bíblico son constantes en las reuniones de indígenas católicos. Al comparar su situación de opresión con la vivida por quienes salieron de Egipto, consiguen analizar su situación, buscar soluciones, encontrar esperanzas para seguir ese camino y motivos para su liberación. 
de construcción de la nueva pastoral indígena. Con el transcurso del tiempo y la consolidación de la praxis catequística, aparece la exigencia de multiplicar las responsabilidades a asumir, llevando consigo la diversificación de roles y funciones. Ello hizo ver la necesidad de delegar parte de esas responsabilidades y, por tanto, la de ampliar el campo de los ministerios indígenas ${ }^{29}$. Entre esos nuevos ministerios pastorales destaca la figura del diácono, la cual ha podido ser definida después de abundantes consultas a la población indígena creyente; ha sido esa población la que ha diseñado su perfil y sus funciones. Uno los rasgos más llamativos es que el diacono debe ser un hombre casado y compartir el diaconado con su esposa. En el horizonte se quiere vislumbrar la posibilidad de que el diaconado acabe dando paso al sacerdocio indígena ${ }^{30}$. Esta nueva pastoral junto con su soporte teórico, la Teología India, están logrando que los indígenas se conviertan en el sujeto básico que determina el rumbo que debe seguir la iglesia católica si quiere llegar hasta ellos. Este movimiento, además, está consiguiendo la revalorización, ya no sólo de sus expresiones religiosas, sino de todas sus manifestaciones culturales, en términos generales. Asimismo, esta organización pastoral está sirviendo como cauce de expansión de su lucha por el reconocimiento de su dignidad humana, social y cultural. Ciertamente, el indígena ha definido un espacio de interrelaciones sociales, en el que está desenvolviendo un proceso alternativo de organización amparándose, para ello, en la seguridad que le proporciona el hecho de mantenerse bajo el paraguas diocesano ${ }^{31}$.

En 2007 tuvo lugar en Aparecida, Brasil, una nueva Conferencia Episcopal donde se discutió la vigencia y la pertinencia de la Pastoral Indígena y de la Teología India. A pesar del clima de desencanto, los indígenas contaron con el apoyo del sector crítico del clero y de determinados obispos, entre ellos, el de San Cristóbal de Las Casas, Monseñor Felipe Arizmendi. Según se colige de las conclusiones del documento final, más allá de las dificultades, las distintas etnias indígenas que desean permanecer formando parte de la iglesia católica, muestran un visible proceso de empoderamiento, como reflejan las siguientes palabras:

Sin que nosotros lo hubiéramos pretendido así, esas mejores flores y también algunas espinas tienen que ver con nosotros, los indígenas del continente, y nos interpelan a todos para mantener con firme esperanza la lucha que hemos retomado de nuestros antecesores, a fin de abrir en la sociedad y en la Iglesia mayores espacios para la reconstitución de las comunidades indígenas como sujetos de la historia y de la fe cristiana... Por eso seguiremos sosteniendo con los demás pobres y excluidos: "Nunca más un mundo sin nosotros, nunca más una Iglesia sin nosotros" (López, 2008: 116-117).

${ }^{29}$ El catequista podrá contar con la colaboración de los coordinadores, celebradores de la Palabra, secretarios, relatores, presidentes de ermitas, coros, etc.

${ }^{30}$ A día de hoy, la Diócesis cuenta con 335 diáconos permanentes y 8000 catequistas (información obtenida de la página web oficial de la Diócesis de San Cristóbal de Las Casas: http://www. diocesisancristobal.com.mx).

${ }^{31}$ Un fenómeno de particular importancia es el proceso de organización de las mujeres indígenas agrupadas en la Coordinadora Diocesana de Mujeres (CODIMUJ) (Gil Tébar, 1999a). 
Es posible que la iglesia chiapaneca haya etnificado su pastoral a través de una reforma de las conductas individuales y colectivas de los indígenas, obteniendo con ello una suerte de perfil ético con el que se busca distinguir - y distanciar - a su feligresía de los católicos de la costumbre - tachados de idólatras y corruptos-y de quienes decidieron abrazar distintas denominaciones protestantes - acusados de ser individualistas y mantenerse en la resignación-. Acotar el campo pasaba por crear un modelo de indígena - persona y comunidad - que se adecuara a los fines liberacionistas y que, para ello, estuviera definido por una serie de características constantemente remarcadas como la solidaridad, la búsqueda del bien común o la vinculación política orientada a luchar contra la opresión y la injusticia La combinación de estas características liberacionistas con algunos rasgos culturales propios - selectivamente rescatados del pasado y elegidos en primera instancia por los agentes de pastoral - han contribuido a diseñar una estrategia de creación de esta nueva línea de identidad étnica desde la propia institución eclesiástica.

No obstante, como ya se mencionó más arriba, lejos de mantenerse en una actitud de pasividad y obediencia ciega a los dictados de la iglesia, las comunidades creyentes relativizan el tutelaje al negociar con la institución los modos y tiempos en que debe desarrollarse la acción pastoral, a la par que hacen uso de los recursos que tal estructura pastoral les facilita para su propio provecho; recursos como la ampliación de la red social más allá de los límites de la aldea o el acceso a un flujo de comunicación por el que dicurren información y noticias que antes difícilmente rozaban sus terruños. Finalmente, sentirse formando parte de una comunidad en la que se comparten tradiciones, creencias religiosas y orientaciones éticas, favorece la consolidación de los vínculos personales que proporcionan estabilidad e, incluso, seguridad, en medio de un ambiente cada vez más proclive a ofrecer múltiples alternativas de identidad, entre las que el individuo puede vagabundear, dispersarse o huir de una tribu a otra sin lealtades preestablecidas (Maffesoli, 2004).

La necesidad sentida de consolidar esta identidad étnica, en medio de un abanico de alternativas que rompe con la homogenidad pasada, tal vez sea la respuesta a la incertidumbre - propia de una globalización que se presenta etnófaga (Díaz Polanco, 2006) - que acosa a quienes han entrado en un entorno social fluido, en constante cambio; un cambio que se ha ido acelerando a un ritmo vertiginoso en las últimas décadas - fuertes flujos de emigración, llegada masiva de turistas y ONG, rebelión zapatista y sus consecuencias, entrada trepidante de los nuevos medios de comunicación, narcotráfico...-, haciendo que se tambaleen los modelos tradicionales de convivencia. La nueva comunidad imaginada entre los indígenas católicos no se reduce a los constreñimientos territoriales de antaño, pues ya no hay aislamiento posible que lo favorezca; la comunidad traspasa la localidad y la localidad puede contener varias comunidades — así lo indica la multiplicación de filiaciones religiosas y políticas - en unos casos irreconciliables, en otros dialogantes.

Tal vez, esta propuesta de identidad busque conjurar los temores que suscita la decadencia de la comunidad, una decadencia que "se perpetúa a sí misma: [puesto que] una vez que se inicia, hay cada vez menos estímulos para contener la desintegración de los lazos humanos y buscar formas de religar lo que se ha desgajado" 
(Baumann, 2003: 59). No se trata tanto de preservar la tradición acríticamente - desde el momento en que el rescate de rasgos es selectivo ${ }^{32}$ - , como de intentar construir una referencia étnica que les resulte más satisfactoria, teniendo en cuenta la correlación que se establece entre sus demandas políticas y religiosas. No hay que olvidar que, en términos generales, los indígenas católicos liberacionistas se identifican con planteamientos políticos que quieren mostrarse críticos a los gobiernos establecidos y que, incluso, presentan tales críticas a la trayectoria que ha ido tomando el zapatismo en Chiapas; un movimiento al que durante un largo período apoyaron sin condiciones ${ }^{33}$.

Chiapas es un complejo mosaico de identidades en el que conviven quienes se autodefinen como los auténticos representantes ya sea de la tradición indígena o de la tradición coleta $^{34}$; turistas llegados de todos los países atraídos por el romanticismo que evocan las imágenes sobre la región; incontables filiaciones religiosas en constante diáspora de sus creyentes ${ }^{35}$; cientos de trabajadores de ONG nacionales y extranjeras que buscan arreglar el mundo o mantenerse económicamente con ese arreglo; y decenas de ciber-cafés que son la punta del iceberg de una nueva urdimbre social. En muy pocos años, el mundo indígena ha tenido que olvidar su aislamiento relativo, ha dejado de permanecer en la penumbra para ser el objetivo de los focos mediáticos. Sin duda, todo ello ha provocado dislocaciones, pérdida de sentidos, curiosidad por otros modos de vida y relación que se presentan más flexibles en sus lealtades y adscripciones. Frente a ese mundo múltiple, fluido, sin referencias estables, sin fronteras - aparentemente-, la propuesta de los católicos liberacionistas - sin dejar de mostrarse abierta y flexible a influencias externas - tal vez sea un intento por no diluirse en la neblina de un mundo en constante mutación, polimorfo, ambivalente y desarraigado.

\section{Reflexiones finales}

A nadie se oculta que las coordenadas teóricas de los dos casos presentados se inscriben en el triángulo religión, etnicidad y política. En este sentido, entendemos que la etnicidad opera en el contraste intercultural estructurando la interacción de dicho contacto, seleccionando para ello ciertos "emblemas de contraste" y determinando una "política de identidad" que es principalmente política de reconocimiento,

${ }^{32}$ Es muy llamativo cómo las mujeres indígenas están reivindicando su derecho a decidir en ese proceso selectivo. Ellas distinguen entre las que consideran buenas y malas costumbres para las mujeres, entre costumbres que hay que conservar y consolidar, y costumbres que hay que modificar o bien eliminar; entre éstas últimas se encuentran la prohibición de poseer tierras, el matrimonio concertado sin tener en cuenta su opinión, o la dificultad de ocupar cargos de gobierno, entre otras.

${ }^{33}$ Valga, en ese sentido, la elección de la iglesia católica, por parte de los zapatistas, como mediadora en el conflicto chiapaneco (Gil Tébar, en prensa).

${ }^{34}$ Coleto es el gentilicio que denomina a los nacidos en la ciudad de San Cristóbal que no sean indígenas. Los descendientes de los expulsados que viven en la periferia, aunque también hayan nacido en la ciudad, no reciben esa denominación.

${ }^{35}$ Desde el catolismo de la costumbre y el liberacionista, a los evangelismos y las distintas versiones del Islam; desde la New Age, a las diversas interpretaciones budistas y los más inesperados sincretismos. 
así como es mecanismo formal de delimitación entre lo intracultural y lo intercultural (Dietz, 2003b: 105). Desde las Ciencias Sociales las religiones han sido frecuentemente abordadas a partir de un énfasis reificador en las creencias, empobreciendo así el análisis de los contextos de producción de la actividad ritual y dificultando el conocimiento de los modos en los que los sistemas religiosos viajan, se hibridan y son reapropiados simbólica y políticamente desde intereses y demandas que dependen de las historias locales. Partiendo de este modo de abordar las prácticas religiosas, tanto el pentecostalismo gitano como el catolicismo liberacionista indígena pueden ser entendidos como dos exponentes de los complejos procesos contemporáneos de etnogénesis, cuya premisa es el juego étnico mediante la reinvención cultural y la producción de argumentos y prácticas que hibridan la cultura autoatribuida y la resignifican desde nuevas claves que piden ser identificadas, todo ello orientado a la acción política y la redefinición simbólica de los límites de la comunidad. Roosens ha explicado cómo los procesos de afirmación y resistencia cultural pueden desdibujarse pero no extinguirse, ya que representan fases dentro de un proceso histórico virtualmente inacabable (Roosens, 1989).

Nuestra reflexión está, por tanto, encaminada a ampliar la discusión teórica en torno a las relaciones entre religión, política y etnicidad, abordado profusamente en las Ciencias Sociales latinoamericanas pero apenas insinuado para el caso, también tratado aquí, de los gitanos españoles. En el primer caso analizado en estas páginas hemos buscado explorar dos hipótesis, porque - primera hipótesis - el asociacionismo pentecostal puede estar favoreciendo nuevas formas de resistencia cultural que, buscando la persistencia de un imaginario cultural autónomo, son puestas en marcha por "segmentos politizados" dentro de los llamados grupos subalternos. Pero — segunda hipótesis_- es también posible que la Iglesia Filadelfia, en tanto que genuino movimiento social de base, represente sin más la otra vertiente de los modelos de resistencia cultural, basada en la eficacia de esas formas cotidianas de resistencia que no se articulan abiertamente como disidencias (Dietz, 2003a). Es más, porque acaso el pentecostalismo político representado por la FACCA esté dejando de practicar esa "etnicidad no conflictiva" que ha venido representando el protestantismo gitano, según hemos postulado en otro lugar (Cantón et al., 2004). En el caso chiapaneco, la etnificación de la pastoral liberacionista, propuesta desde la instancia eclesiástica, posiblemente responda a la necesidad de marcar límites respecto a las restantes alternativas religiosas e, incluso, constituya una estrategia de contrapeso a los poderes establecidos - desde el momento en que la iglesia rompe su alianza con los mismos- - Pero ello no ha impedido que la población destinaria haga suya esa iniciativa, resignificando consciente y selectivamente su identidad y valiéndose del amparo eclesiástico para la práctica de su resistencia política.

En ambos casos hemos visto cómo se hace cada vez más necesario recoger y explorar etnográficamente los relatos de coherencia, esto es, las narrativas que resignifican el sentido de pertenencia a un grupo étnico desde los nuevos vínculos religiosos, asociativos y políticos, abriendo espacios alternativos para reconocerse, tejiendo redes nuevas de solidaridad y contribuyendo al surgimiento de una nueva forma de agencia política, de grupos de poder regional y local. Así, los saberes y 
discursos que atraviesan las narrativas de pertenencia e identidad nos remiten, de ahí su interés etnográfico, al juego de las múltiples escalas de acción que conforman la vida cotidiana. Es, por tanto, una noción que desdibuja las fronteras estables de las culturas e impugna el uso frecuentemente reificador que hacemos de los etnónimos. Cuanto más acabadas son las representaciones, los relatos de coherencia y los diagnósticos que ofrecen las Ciencias Sociales, más susceptibles de discusión parecen. Para elaborarlos necesitamos distancia y, por lo común, cuanto más distante es la mirada que dirigimos a un campo de relaciones sociales, "cuanto menos local y más acabada es su panopsis", más nítidas aparecen sus fronteras —étnicas, religiosasEsas mismas fronteras se desdibujan, ondulan, mezclan o burlan de nosotros, a medida que nos aproximamos a las prácticas concretas. Así:

En su vinculación biográfica, y por tanto vivida, con determinados sistemas expertos, y en particular con las instituciones escolares y políticas, y en su formación en las esferas de pertenencia íntimas, como la familia o la amistad, los agentes construyen sus particulares relatos de coherencia y, con arreglo a estos relatos, apelan eventualmente a sus derechos a la identidad (Díaz de Rada, 2008: 230).

Entendemos que estas páginas tienen el valor, si poseen alguno, de contribuir una vez más a contrapesar los abordajes reificadores y esencialistas de las identidades étnicas, los que apenas dejan ver la producción de diversidad dentro de la diversidad y reconocer los múltiples oráculos en competencia de los que dispone una "cultura" - gitana, tzotzil, tzeltal o chol-y, por tanto, lo inapropiado de su consideración como un todo compacto, autocontenido, homogéneo, producto de una visión cómodamente estática y conservadora de los contenidos de la cultura. La cultura, más que designar una autoevidencia de límites concretos, es a veces semejante a un perturbador juego de espejos o a una ilusión de perspectivas. Dentro de la abusada noción habita un nosotros imaginario, histórico y mudable, hecho de divisiones, complicidades y tensiones sólo observables en el flujo de la vida social, en el ruido cotidiano, en los vericuetos de las prácticas sociales y en el entrecruzamiento de sujetos políticos implicados en su definición. Las concepciones primordialistas o dicotómicas de la identidad étnica siguen estando analíticamente presentes, de un modo a veces sólo maquillado, pese a que seamos cada vez más conscientes de los lastres que una noción dura y ahistórica de las identidades impone a la comprensión de la vida social como algo que tiene lugar en un campo de relaciones de poder, en el flujo y la interacción ${ }^{36}$.

Estas páginas también dejan ver los desbordamientos de tradiciones en movimiento perpetuo, en procesos de hibridación e intercambio vertebrados por la fuerza de las filiaciones religiosas, así como la capacidad de agencia y empowerment que desencadenan los usos políticos de los vínculos religiosos, los asociacionismos con-

${ }^{36}$ Desde las antípodas del constructivismo, Wolf llega a afirmar: "Ni las sociedades ni las culturas deberían darse por supuestas, como si estuvieran configuradas por una esencia interna, una organización fundamental o un plan magistral, sino que las series culturales y las series de series están continuamente en construcción, deconstrucción y reconstrucción, bajo el impacto de múltiples procesos que afectan a varios campos de conexiones sociales y culturales" (Wolf, 1984). 
fesionales o el diálogo institucional a través de las nuevas agencias mediadoras. Y sobre todo estas páginas buscan mostrar cómo la subalternidad no puede servirnos de coartada para reducir a los grupos, como si únicamente los volviera visibles su condición de víctimas. La etnicidad se juega en contextos concretos y se mide en escalas de prácticas que piden ser ilustradas, espacios cotidianos de interacción, legitimidades que se imponen o interseccionan según circunstancias y procesos históricos muy diversos de mediación y poder, que pueden ser identificados a través de la observación etnográfica.

Hay modos en los que todo ello puede también ampliar la reflexión sobre las condiciones epistemológicas y empíricas en las que tiene lugar el trabajo etnográfico en las condiciones marcadas por la movilidad y la aceleración contemporáneas y que, como postulan algunos autores, aconsejan redefinir las convenciones del modelo clásico malinowskiano en el que nos hemos venido inspirando desde mediados del pasado siglo. También para, de este modo, poder dar cuenta etnográfica de los entrecruzamientos e intersecciones tardomodernos entre lo tradicional, lo urbano y lo masivo (García Canclini, 1989: 232-235). Ya no es posible dejar de preguntarse por las condiciones epistemológicas y prácticas en las que producimos nuestro conocimiento científico sobre las complejas realidades definidas como religiosas. Todo esto forma parte constitutiva de la propia conformación del objeto de estudio: qué estudiamos, por qué y cómo lo hacemos; la reflexión sobre las relaciones que se establecen en el campo con los agentes de culto y los miembros de las organizaciones religiosas; la perplejidad de quienes se valen de la razón para entender juegos del lenguaje que disponen de su propia lógica; la circularidad de significados en las relaciones de campo entre investigados y expertos; la misma entrada en competencia de discursos expertos sobre la cultura, la religión, la tradición, política o la identidad. Y, desde luego, todo ello condiciona y sesga el resultado de nuestras investigaciones en direcciones que a veces caen más allá de nuestro control y que sólo perpetúan inercias. Consideradas reflexivamente, muchas investigaciones sobre religión pueden ser leídas del revés y proporcionarnos más información sobre las categorías-fetiche de los investigadores que sobre los propios grupos y problemas estudiados. Acaso es inevitable; a fin de cuentas la etnografía es también alegoría.

\section{Referencias bibliográficas}

AGUIRRE BELTRÁN, Gonzalo

1987 Regiones de refugio. México: Fondo de Cultura Económica.

ANZALDO, Carlos; PRADO, Minerva

2006 Índices de marginación, 2005. México: CONAPO.

BAUMANN, Zygmunt

2003 Comunidad. En busca de seguridad en un mundo hostil. Madrid: Siglo XXI.

BERGER, Peter Ludwig

1981 Para una teoría sociológica de la religión. Barcelona: Cairos. 
BOURDIEU, Pierre

1988 "La disolución de lo religioso", en P. Bourdieu, Cosas dichas. Barcelona: Gedisa.

CANTÓN, Manuela

1998 Bautizados en fuego. Protestantes, discursos de conversión y política en Guatemala (1989-1993). Vermont, La Antigua: Plumsock Mesoamerican Studies y CIRMA.

2003 "Religiones globales, estrategias locales. Usos políticos de las conversiones en Guatemala", en B. Pérez y G. Dietz (eds.), Globalización, resistencia y negociación en América Latina. Madrid: Los Libros de la Catarata, 103-125.

2010 "Gypsy Pentecostalism, Ethnopolitical Uses and Construction of Belonging in the South of Spain”. Social Compass, 57, 2: 253-267.

CANTÓN, Manuela; et al.

2004 Gitanos pentecostales. Una mirada antropológica a la Iglesia Filadelfia en Andalucía. Sevilla: Signatura Ediciones.

CORNEJO VALLE, Mónica

2008 La construcción antropológica de la religión. Etnografía de una comunidad manchega. Madrid: Ministerio de Cultura.

CORTEN, André; MARY, André (Eds.)

2001 Between Babel and Pentecost. Transnacional Pentecostalism in Africa and Latin America. London: Hurst.

DÍAZ DE RADA, Ángel

2008 ¿Dónde está la frontera? Prejuicios de campo y problemas de escala en la estructuración étnica en Sapmi”. Revista de Dialectología y Tradiciones Populares, LXIII1: 187-235.

DÍAZ POLANCO, Héctor

2006 El laberinto de la identidad. México: UNAM.

DIETZ, Gunther

2003a “Introducción”, en B. Pérez y G. Dietz (eds.), Globalización, resistencia y negociación en América Latina. Madrid: Los Libros de la Catarata, 9-39.

2003b Multiculturalismo, interculturalidad y educación: una aproximación antropológica. Granada: Universidad de Granada, CIESAS.

FOSTER, George M.

1976 Tzintzuntzan: los campesinos mexicanos en un mundo en cambio. México: Fondo de Cultura Económica.

FRESNO, J. M.

1991 "Dictamen sobre la articulación de la participación social y movimiento asociativo", en Estudio Sociológico sobre la comunidad gitana en España. Marco Teórico. Madrid: Asesoría de Programas de Servicios Sociales (P.A.S.S.), 1-103.

FRESTON, Paul

2001 Evangelicals and Politics in Asia, Africa and Latin America. Cambridge: Cambridge University Press. 
GAMELLA, Juan Francisco (Coord.)

1996 La población Gitana en Andalucía. Sevilla: Consejería de Trabajo y Asuntos Sociales de la Junta de Andalucía.

GARCÍA CANCLINI, Néstor

1989 Culturas hibridas. Estrategias para entrar y salir de la modernidad. México: Grijalbo.

GEERTZ, Clifford

1988 "La religión como sistema cultural”, en La interpretación de las culturas. Barcelona: Gedisa, 87-117.

GIL TÉBAR, Pilar

1999a Caminando en un solo corazón. Las mujeres indígenas de Chiapas. Málaga: Universidad de Málaga.

1999b "Recreando la palabra. La Teología India y la Pastoral Indígena en la Diócesis de San Cristóbal de Las Casas (México), en S. Rodríguez Becerra (coord.), Religión y Cultura. Sevilla: Signatura Demos, 395-402.

En prensa "Migración, religión y construcción de la ciudadanía: las mujeres indígenas católicas en la ciudad de San Cristobal de Las Casas (Chiapas, México)", en Autoctonía, poder local y espacio global frente a la noción de ciudadanía. Barcelona: Universidad de Barcelona.

En prensa "The Catholic Church as Mediator in Chiapas Conflict", en J. Faget (coord.), Mediation in Political Conflicts: Soft Power or Counter Culture? Oxford: Hart Publishing.

GLIZE, R.

1989 "L'Eglise Evangelique Tsigane comme voie possible d'un engagement culturel nouveau". Actes du Cólloque pour le trentiénne anniversaire des Etudes Tsiganes, 433-443.

GONZÁLEZ ESPONDA, Juan

1992 "El Congreso Indígena de 1974: contexto y consecuencias". Memorias del Primer Congreso de Mayistas, 165-182.

KORSBAEK, Leif; SÁMANO RENTERÍA, Miguel Ángel

2007 "El indigenismo en México: antecedentes y actualidad". Ra Ximhai, III-1: 195-224.

LÓPEZ, Eleazar

2008 "La Teología India en la Iglesia. Un balance después de Aparecida" Revista Iberoamericana de Teología, 6: 87-117.

MAFFESOLI, Michel

2004 El nomadismo. Vagabundeos iniciáticos. México: Fondo de Cultura Económica.

ROOSENS, Eugene

1989 Creating Ethnicity. The Process of Ethnogenesis. London: Sage. 
SÁNCHEZ CARRETERO, Cristina

2008 'La creencia en la 'no-creencia' de los espíritus y otras cartografías de lógicas religiosas: El caso de los centros de portadoras de misterios dominicanos en Madrid", en M. Cornejo, M. Cantón y R. Llera (coords.), Teorías y prácticas emergentes en Antropología de la Religión. Universidad del País Vasco, 253-272.

SANSI, Roger

2007 “Intenció i atzar en la historia del fetitxe". Quaderns de L'Institut Català d'Antropologia, 23.

SAN ROMÁN, Teresa

1997 La diferencia inquietante. Viejas y nuevas estrategias culturales de los gitanos. Madrid: Siglo XXI.

2006 “Acaso es evitable? El impacto de la Antropología en las relaciones e imágenes sociales”. Revista de Antropología Social, 15: 373-410.

VV. AA.

1975 "Declaración de Barbados I", en VV. AA., Por la liberación del indígena. Documentos y testimonios. Buenos Aires: Ediciones del Sol, 20-31.

VV. AA.

1994 “Declaración de Barbados III”. Ojarasca, 33-34: 38-42.

WEBER, Max

1992a “Los tipos de dominación”, en Economía y sociedad. México: FCE, 170-241.

1992 b "Sociología de la comunidad religiosa", en Economía y sociedad. México: FCE, $328-492$.

WILLIAMS, P.

1991 "Le miracle et la nécessité: à propos du développement du Pentecôstisme chez les Tsiganes”. Extraits Archives des Sciences Sociales des Religions, 73:71-88.

WOLF, Eric R.

1981 "Comunidades corporativas cerradas de campesinos en Mesoamérica y Java Central”, en J. Llobera (ed.), Antropología Económica. Estudios Etnográficos. Barcelona: Anagrama, 81-100.

1984 “La cultura, ¿panacea o problema?”. American Antiquity, 49: 393-400. 
